\section{CardioRenal Medicine}

\title{
Possible Mechanisms of Local Tissue Renin-Angiotensin System Activation in the Cardiorenal Metabolic Syndrome and Type 2 Diabetes Mellitus
}

\author{
Melvin R. Hayden ${ }^{a, c}$ Kurt M. Sowers ${ }^{e}$ Lakshmi Pulakat ${ }^{a, c, d}$ \\ Tejaswini Joginpally ${ }^{c}$ Bennett Krueger ${ }^{c}$ Adam Whaley-Connell ${ }^{a, c, d}$ \\ James R. Sowers ${ }^{\text {a-d }}$ \\ Departments of a Internal Medicine and ${ }^{b}$ Physiology and Pharmacology, University of Missouri- \\ Columbia School of Medicine, 'Diabetes Cardiovascular Center, and d Harry S. Truman VA Medical \\ Center, Columbia, Mo., and ${ }^{\mathrm{e}}$ Kidney Specialists of Southern Nevada, Henderson, Nev., USA
}

\section{Key Words}

Adipose tissue $\cdot$ Insulin resistance $\cdot$ Mast cells $\cdot$ Reactive oxygen species $\cdot$ Redox stress $•$

Renin-angiotensin system $\cdot$ Type 2 diabetes mellitus

\begin{abstract}
The role of local tissue renin-angiotensin system (tRAS) activation in the cardiorenal metabolic syndrome (CRS) and type 2 diabetes mellitus (T2DM) is not well understood. To this point, we posit that early redox stress-mediated injury to tissues and organs via accumulation of excessive reactive oxygen species (ROS) and associated wound healing responses might serve as a paradigm to better understand how tRAS is involved. There are at least five common categories responsible for generating ROS that may result in a positive feedback ROS-tRAS axis. These mechanisms include metabolic substrate excess, hormonal excess, hypoxia-ischemia/reperfusion, trauma, and inflammation. Because ROS are toxic to proteins, lipids, and nucleic acids they may be the primary instigator, serving as the injury nidus to initiate the wound healing process. Insulin resistance is central to the development of the CRS and T2DM, and there are now thought to be four major organ systems important in their development. In states of overnutrition and tRAS activation, adipose tissue, skeletal muscle (SkM), islet tissues, and liver (the quadrumvirate) are individually and synergistically related to the development of insulin resistance, CRS, and
\end{abstract}




\section{CardioRenal Medicine}

T2DM. The obesity epidemic is thought to be the driving force behind the CRS and T2DM, which results in the impairment of multiple end-organs, including the cardiovascular system, pancreas, kidney, retina, liver, adipose tissue, SkM, and nervous system. A better understanding of the complex mechanisms leading to local tRAS activation and increases in tissue ROS may lead to new therapies emphasizing global risk reduction of ROS resulting in decreased morbidity and mortality.

Copyright $\odot 2011$ S. Karger AG, Basel

\section{Introduction}

The renin-angiotensin-aldosterone system (RAS) has captivated clinicians and researchers alike since Tigerstedt and Bergman recognized in 1898 that there were pressor effects of a rabbit renal extract they termed renin [1]. A constitutive RAS is present, and the human body maintains an ample supply of renin (the rate-limiting enzyme of the RAS) stored as renin-secretory granules (RSG) within the renal juxtaglomerular apparatus (fig. 1). Importantly, the renal myoendocrine vascular smooth muscle cells of the afferent arteriole or juxtaglomerular cell must be activated for secretion of renin from the RSG. A recent pertinent review discusses the importance of a local RAS (local angiotensin-converting enzyme, ACE, in endothelium and muscle) [2]. Currently, two distinct angiotensin (Ang) II-generating systems are recognized in animal models and humans: (1) the constitutive, circulating, and endocrine-hormonal RAS (cRAS) that systemically acts as a regulatory and survival system promoting cardiovascular homeostasis, and (2) a local tissue autocrine/paracrine AngIIgenerating system (tRAS).

The specific human substrate precursor protein for this complex enzymatic-hormonal system (cRAS), angiotensinogen, is a $60-\mathrm{kDa} \alpha_{2}$-globulin glycoprotein with 452 amino acids produced primarily in the liver [3]. The human rate-limiting mature 340 -amino-acid $37-\mathrm{kDa}$ primarily renal-derived renin enzyme [4] then cleaves angiotensinogen to the physiologically inactive decapeptide AngI. This decapeptide is then hydrolyzed to the physiologically active effector octapeptide AngII by the 1,306-amino-acid 140-kDa zinc-containing metallopeptidase ACE [5]. Subsequently, this effector peptide (AngII) binds to its membranous angiotensin receptors, resulting in its physiological effects, e.g. in the adrenal gland where AngII activates the increased synthesis of aldosterone (fig. 2). The systemic RAS is important in the regulation of blood pressure, and electrolyte and volume homeostasis. It is normally activated by sodium and/or volume depletion as occurs with dehydration, trauma, and shock (survival mechanisms). These mechanisms involve reduced renal perfusion pressure, reduced salt transport to the distal tubule, or increased renal sympathetic tone at the level of the juxtaglomerular apparatus, which activate renin secretion. Ideally, these mechanisms should be rapidly activated and short lived once vascular homeostatic balance is achieved [6].

In contrast, tRAS is especially important in pathophysiological states, and this autocrine/paracrine system is activated by local tissue injury. These injuries are frequently a result of increased tissue inflammation, injury including trauma, hypoxia-ischemia/ischemiareperfusion, hormonal excess (insulin, proinsulin, and amylin), and hyperglycemia, hyperlipidemia, hyperhomocysteinemia, and hyperuricemia (fig. 3). Collectively, these tissueinjury factors are associated with the generation of reactive oxygen and subsequent reactive nitrogen species referred to as reactive oxygen species (ROS). Importantly, these ROS are generated by membranous and cytosolic nicotine adenine dinucleotide (phosphate) reduced $[\mathrm{NAD}(\mathrm{P}) \mathrm{H}]$ oxidase, mitochondrial leakage, xanthine oxidase enzyme, tetrahydrobiopterin coenzyme oxidation, and resulting endothelial nitric oxide (NO) synthetase (eNOS) uncoupling. 


\section{CardioRenal Medicine}

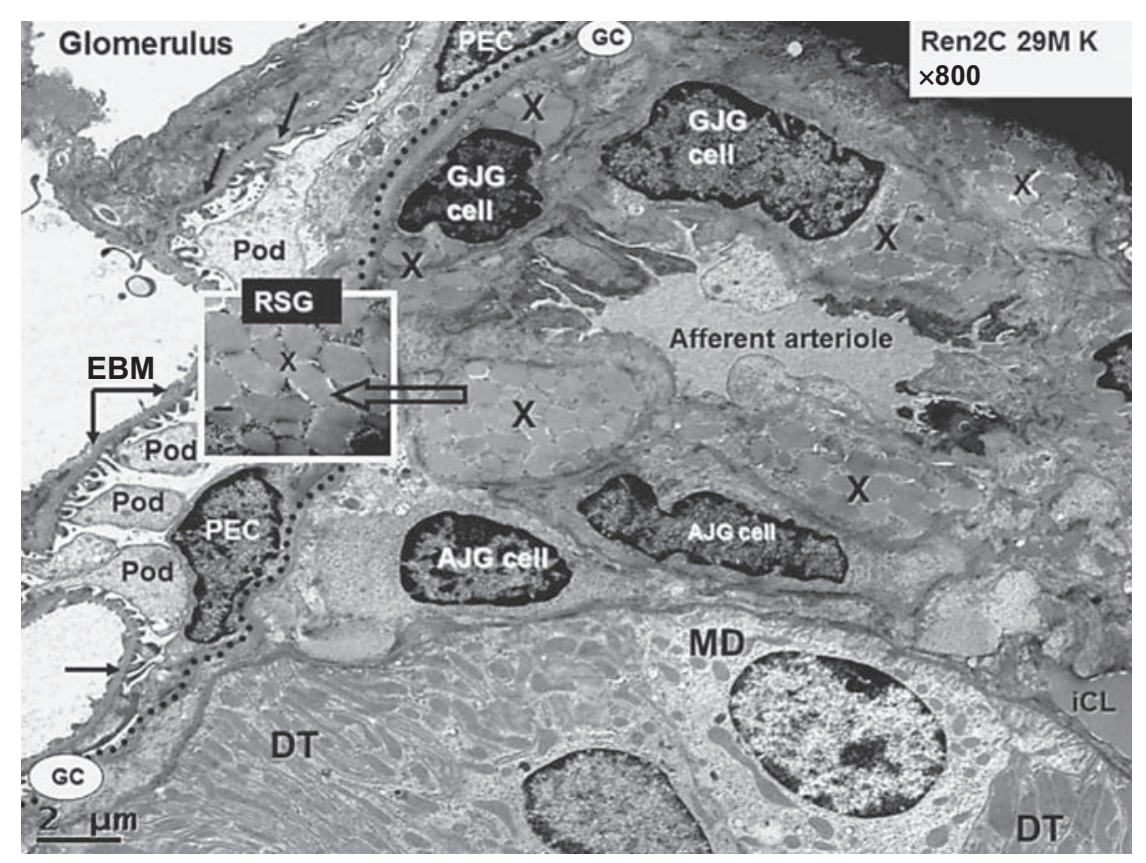

Fig. 1. Juxtaglomerular apparatus depicting RSG. This transmission electron micrograph from a young transgenic Ren 2 rat model of hypertension and insulin resistance demonstrates the renal glomerulus separated by Bowman's glomerular capsule (GC; dotted line) from the adjacent juxtaglomerular apparatus, which includes the afferent arteriole, the distal tubule (DT), which bisects the afferent and efferent arterioles in each nephron containing the macula densa (MD) cell(s). The afferent arteriole demonstrates the granular juxtaglomerular cells (GJG) containing RSG (X) and agranular or depleted juxtaglomerular (AJG) cells. Inset depicts RSG at higher magnification (open arrow; $\times 8,000$; bar $=200 \mathrm{~nm}$ ). Note the visceral epithelial cell(s) termed podocyte(s) (Pod) with their cytoplasmic processes and parietal epithelial cells (PEC) at the periphery of the glomerulus and the podocyte foot processes adhering to the endothelial basement membrane (EBM; closed arrows) within the glomerulus. The interstitial capillary lumen (iCL) in the lower right-hand side of the image is thought to be the major site of renin absorption and subsequent delivery to the systemic circulation.

Pathophysiological states including hypertension, vascular injury, cardiorenal metabolic syndrome (CRS), type 2 diabetes mellitus (T2DM), and cancer are all associated with tRAS activation [6-30]. In contrast to the more rapid acting cRAS providing cardiovascular homeostasis, tRAS is more of a subacute-maintenance/remodeling compartmental system which promotes tissue remodeling (proliferation, hypertrophy, and differentiation) and extracellular matrix (ECM) remodeling repair and/or fibrosis. The sustained activation of tRAS in chronic diseases with persistent local tissue injury may also result in parenchymal loss (via apoptosis/necrosis and autophagy) and chronic remodeling and fibrosis with eventual end-organ dysfunction.

While the multiple pathophysiological states previously iterated are associated with tRAS activation, we will focus on CRS and T2DM, since they are associated with multiple end-organ remodeling and the multiple diseases or diabetic 'opathies' (cardiomyopathy, intimopathy, isletopathy, hepatopathy, glomerulo-tubulopathy, neuropathy, and retinopathy). Because the mechanisms of tRAS activation are not well understood or elucidated in the literature, we hypothesize that injury to tissues and organs via ROS/redox stress and tissue wounding injury and the subsequent obligatory innate wound healing response might serve as a tRAS activation paradigm (fig. 3,4 ). 


\section{CardioRenal Medicine}

Cardiorenal Med 2011;1:193-210

\begin{tabular}{l|l}
\hline DOI: $10.1159 / 000329926$ & (c) 2011 S. Karger AG, Basel
\end{tabular}

Published online: July 30, 2011

Hayden et al.: Mechanisms of Local tRAS Activation

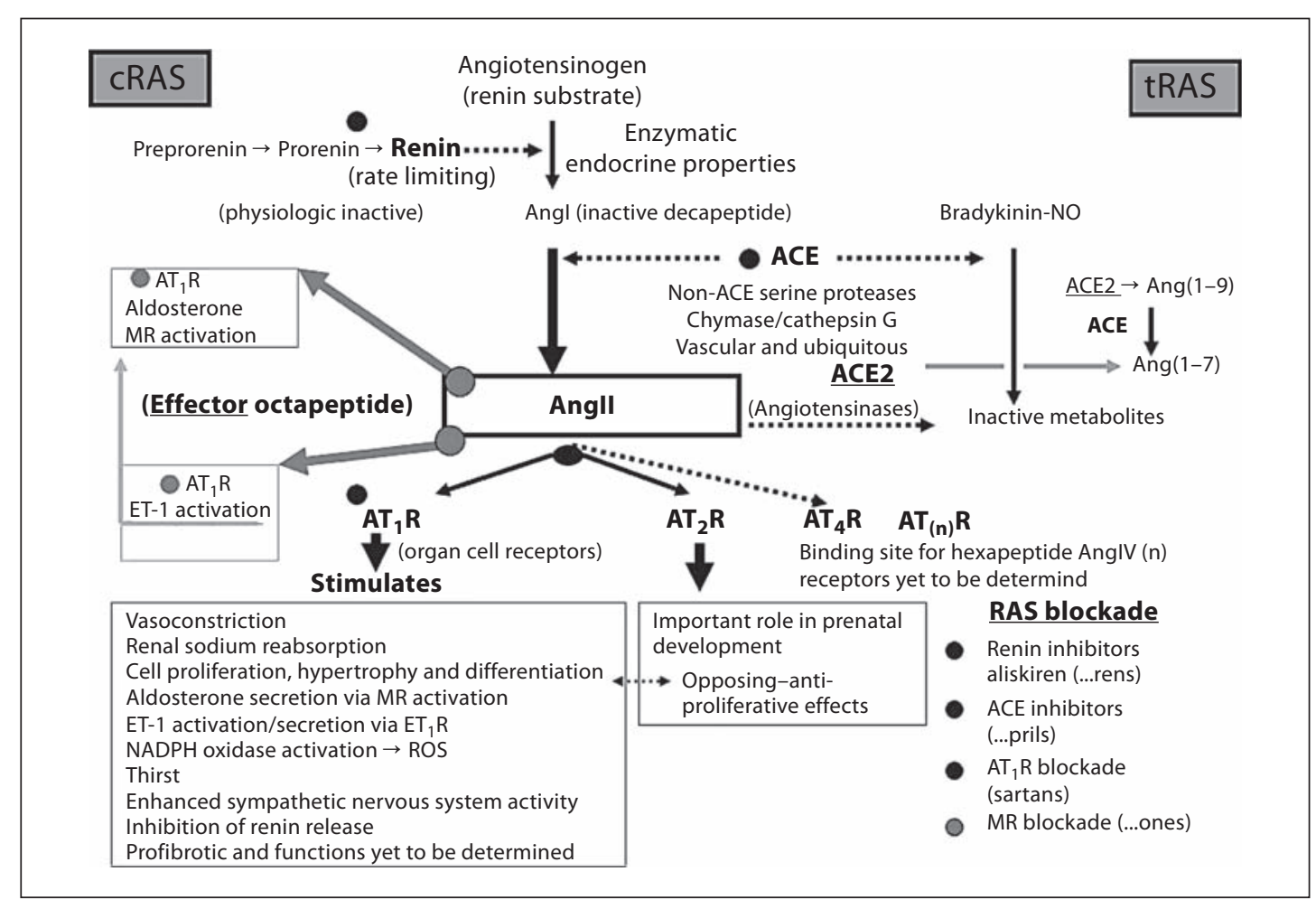

Fig. 2. Schematic of the enzymatic-hormonal RAS. The RAS is an exciting enzymatic cascade responsible for physiologic and pathophysiological effects. Angiotensinogen is the only known substrate for the ratelimiting enzyme renin to produce the physiologic inactive decapeptide AngI. This decapeptide is cleaved by ACE to generate the physiologically effector octapeptide AngII, which has its primary physiologic/ pathophysiological actions via $\mathrm{AT}_{1} \mathrm{R}$. RAS blockade with the pharmacologic renin inhibitor aliskiren, ACE inhibitors (multiple), and $\mathrm{AT}_{1} \mathrm{R}$ antagonist blockers (multiple) has provided clinicians a means of blocking these deleterious effects of the enzymatic-hormonal system when it is chronically activated (systemically or at the local tissue level) resulting in hypertension and end-organ tissue damage. These antihypertensive, anti-inflammatory, antioxidant, and antifibrotic medications provide protection to the involved end-organs and result in decreased morbidity and mortality. MR = Mineralocorticoid receptor.

\section{The Existence of a Local tRAS in Various Organ Systems}

The importance of tRAS has been increasingly recognized since renin was initially found to be present in the dog brain [31]. This local AngII-generating system has been identified in various targeted end-organs, such as the heart, kidney, vasculature, skeletal muscles $(\mathrm{SkM})$, liver, pancreas, retina, and adipose, neuronal, and reproductive tissues [6-30]. In addition to local hemodynamic effects, tRAS and its effector peptide AngII contribute to the regulation of cell growth, proliferation, apoptosis, differentiation, tissue inflammation, hormonal secretion, and fibrosis in concert with (and/or independent of) cRAS. Importantly, tRAS also contributes to further generation of ROS via the effects of AngII on the angiotensin type 1 receptor $\left(\mathrm{AT}_{1} \mathrm{R}\right)$ activating a membranous non-phagocytic NADPH oxidase enzyme. This additional $\mathrm{AT}_{1} \mathrm{R}$ activation results in a vicious cycle of ROS production within the wounded organs, i.e. RAS begets ROS.

Importantly, there may be a sequential activation of the renal ROS-tRAS axis in CRS, T2DM, and diabetic nephropathy, in that the Zucker diabetic fatty rat developed hyperglycemia/diabetes at 12 weeks of age. This was followed by increased 8-isoprostane levels at 15 


\section{CardioRenal Medicine}

\begin{tabular}{l|l}
\hline Cardiorenal Med 2011;1:193-210 \\
\hline $\begin{array}{l}\text { DOI: 10.1159/000329926 } \\
\text { Published online: July 30, 2011 }\end{array}$ & $\begin{array}{l}\text { @ 2011 S. Karger AG, Basel } \\
\text { www.karger.com/crm }\end{array}$ \\
\hline
\end{tabular}

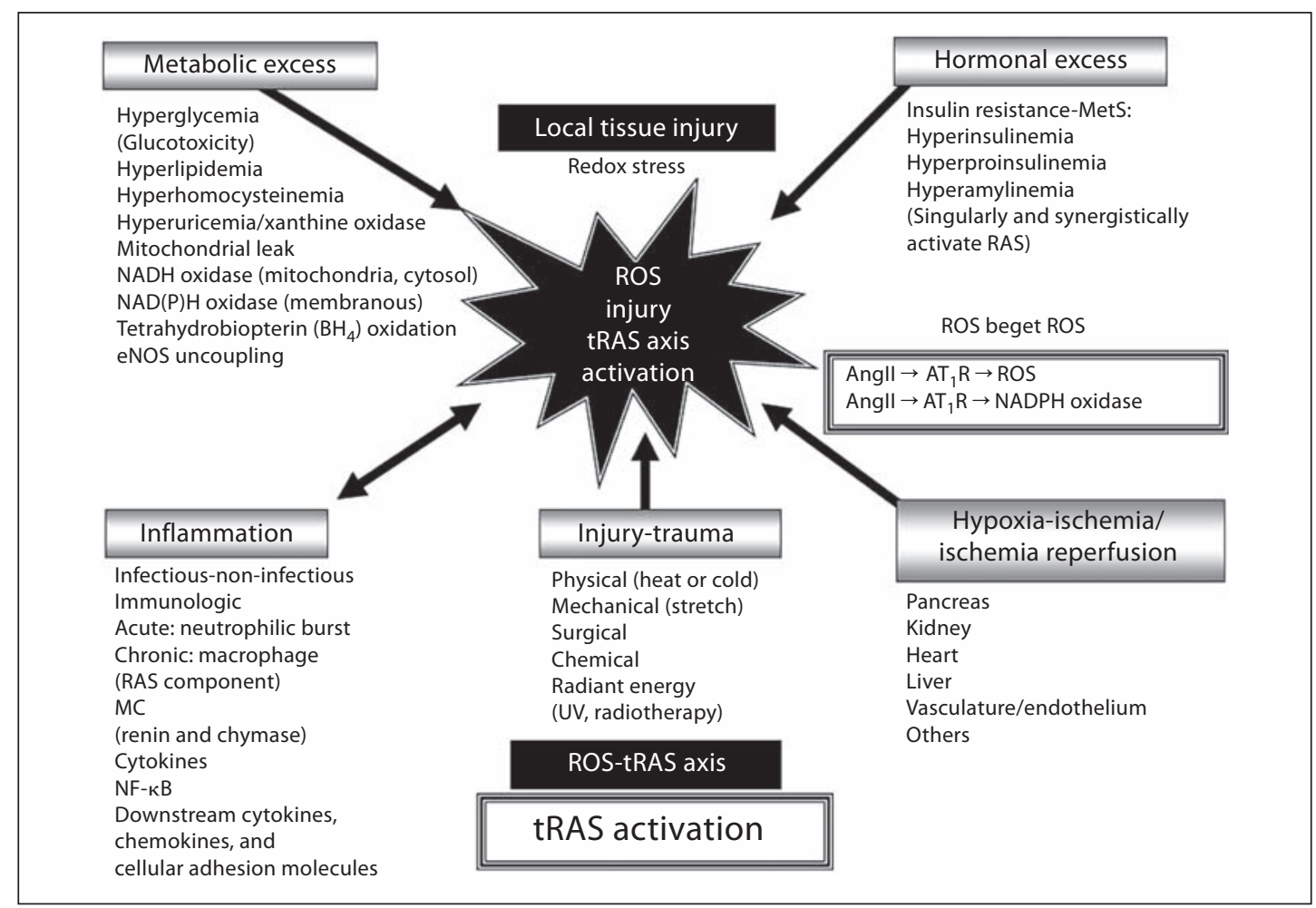

Fig. 3. Unifying theme for local tRAS activation in CRS and T2DM. ROS are responsible for injury to proteins, lipids, and nucleic acids. There are at least five major categorical mechanisms that are responsible for the generation of the injurious ROS in animal models and humans with subsequent tRAS activation in the CRS and T2DM. While acute trauma is thought to be primarily involved in the cRAS, chronic/recurrent trauma/injury is felt to be linked to local tRAS activation and may be a contributing mechanism to the development of recurrent ROS and tissue injury. Chemical trauma would include such chemicals as carbon tetrachloride-dioxin-alloxan-streptozotocin and radiant energy would include ultraviolet sun damage and radiotherapy. In addition to CRS and T2DM, there are cardiovascular diseases including hypertension, atherosclerosis, vascular injury, and congestive heart failure, chronic kidney disease, neurological diseases, obesity, and cancer, which are associated with tRAS activation. As a result of these multiple injurious mechanisms resulting in excess generation of ROS and the subsequent activation of a tRAS, we feel there develops a ROS-tRAS axis.

weeks (reflecting increased ROS/oxidative stress), increased cortical angiotensinogen levels at 18 weeks, and increased levels of AngII (glomerular and tubular) and glomerular desmin/ Masson's trichrome staining indicating fibrosis in the tubular interstitium at 21 weeks [32]. These findings support a role for sequential activation of the ROS-tRAS axis in a CRS animal model and further implicate the important role of ROS as possibly being the initiating injury triggering tRAS activation and the innate wound healing response to injury (fig. 4).

\section{The Innate Wound Healing Response to Injury}

Systemic blood elements (inflammatory cells and platelets), soluble mediators (growth factors and cytokines), ECM, and native tissue parenchymal and interstitial cells interact in a dynamic fashion to result in the normal repair and healing of injured tissue (fig. 4). These dynamic innate and obligatory wound repair/healing processes can be grouped into tempo- 


\section{CardioRenal Medicine}

Cardiorenal Med 2011;1:193-210

DOI: $10.1159 / 000329926$

Published online: July 30, 2011

Hayden et al.: Mechanisms of Local tRAS Activation

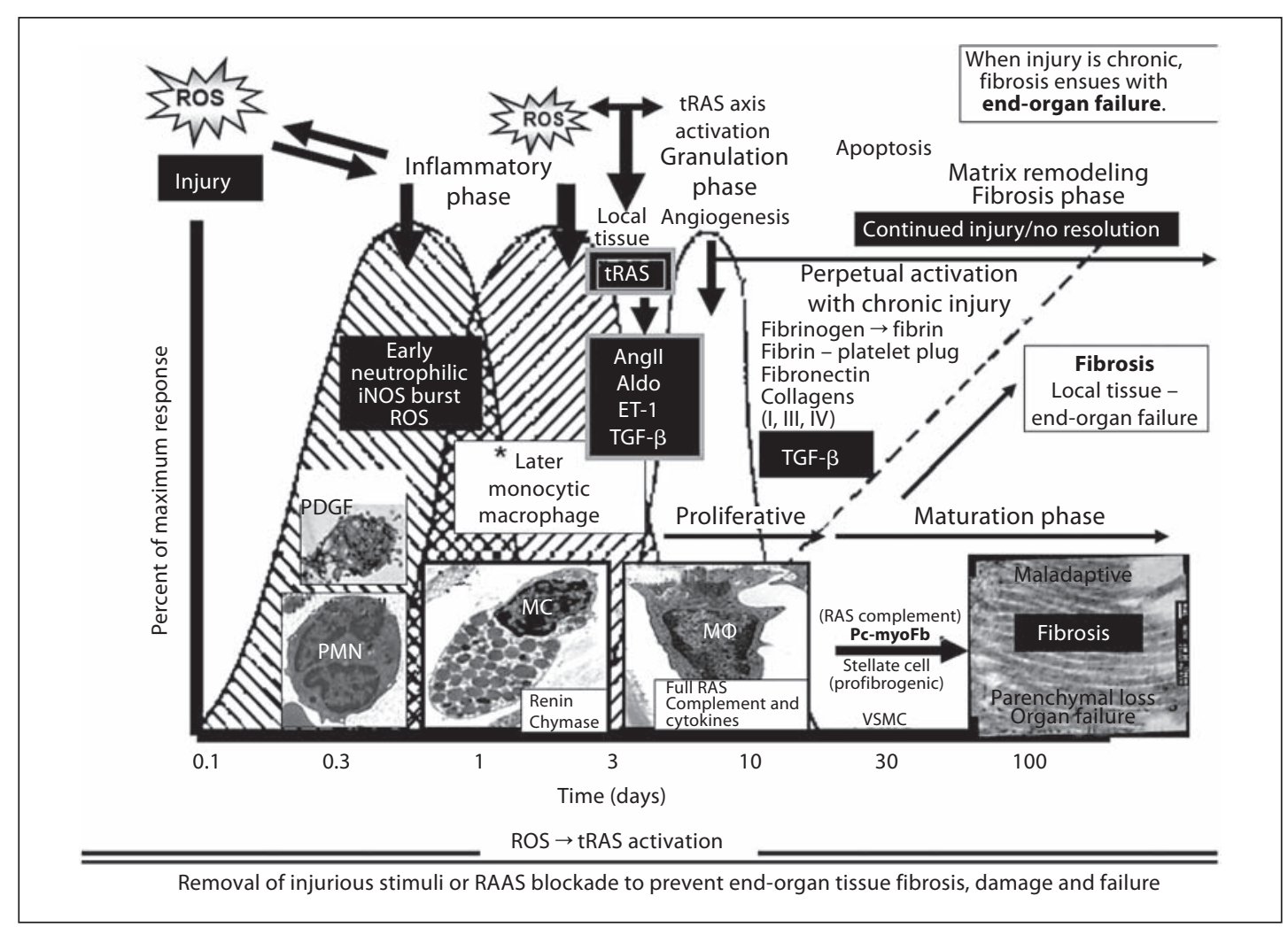

Fig. 4. The innate local tissue wound healing response to injury. There is a commonality of organ-tissue injury to cutaneous wound repair [33]. The intended goal of the innate local tissue wound repair and healing response to injury is the return to wholeness or recovery - 'restitutio ad integrum'. The generation of ROS as a result of metabolic, hormonal, and inflammatory injury, hypoxia, and recurrent trauma mechanisms in the CRS and T2DM is the injury responsible for the activation of the local tissue wound healing response. The injurious process is chronic as it is in the CRS and T2DM; however, the wound healing process does not result in recovery or a return to wholeness. Instead, it results in excessive ECM accumulation with fibrosis and scarring. The sequential and overlapping processes of hemostasis (platelets: platelet-derived growth factor, PDGF, and innate clotting factors), inflammation (acute and chronic, including activation and degranulation of resident MC), proliferation/granulation phase, ECM maturation/remodeling maturation and resolution/recovery are lost if the wound healing response is chronic and ongoing due to continued injury by ROS and strongly implicates a ROS-tRAS axis. Currently, the authors feel that the tRAS axis is activated in and around the inflammatory phase/granulation-proliferative and maturation phase nexus. Activated resident MC, chronic inflammatory cells, and fibrogenic cells along with tRAS activation, AngII generation along with aldosterone (Aldo) and ET-1, and TGF- $\beta$ result in excessive ECM accumulation and fibrosis if tRAS is chronically activated. Importantly, MC are known to contribute renin and chymase from their secretory granules, the macrophage contains a full RAS complement, and the profibrotic myofibroblasts/pericytes or stellate cells contain a full RAS complement contributing to the maladaptive ECM remodeling fibrosis resulting in organ dysfunction and failure. Insets depict platelets, polymorphonuclear neutrophils $(\mathrm{PMN})$, acute inflammatory cells $(\mathrm{MC})$, chronic inflammatory cells [macrophages $(\mathrm{M} \Phi)$ ], and maladaptive ECM accumulation of collagen with end-organ fibrosis, dysfunction, and eventual failure.

ral overlapping phases including injury, inflammation, granulation (proliferative phase including angiogenesis and fibroblast-myofibroblast, stellate cell, or pericyte infiltration), and ECM remodeling, repair, restructuring, and resolution [33, 34]. If the local tissue injury is persistent or recurrent then ECM fibrosis may occur with ensuing parenchymal loss (necrosis/apoptosis), adipose tissue deposition, and eventual organ failure due to fibrosis and scar- 


\section{CardioRenal Medicine}

ring. Because ROS seem to be the instigator of most chronic disease injuries in CRS and T2DM, we have chosen to utilize the generation of excess ROS as a critical juncture in local tissue wound healing responses to injury (fig. 4). Regardless of the etiological agent(s), ECM remodeling fibrosis of most chronic diseases represents a final common pathway leading to the destruction of tissue architecture and function, and subsequent organ failure [35].

\section{Vascular Endothelial Dysfunction as a Critical Abnormality in CRS and T2DM}

NO exerts a plethora of beneficial vascular effects, including its local immediate chainbreaking antioxidant (ROS-scavenging effects), anti-inflammatory, antithrombotic, antifibrotic, anti-atherosclerotic, cytoprotective, and vasodilatatory effects. Reduced bioavailable $\mathrm{NO}$ and associated endothelial dysfunction are early and central findings in the capillary bed in both CRS and T2DM [36]. There are multiple end-organs that are contemporaneously being injured in CRS and T2DM, and this can be partially explained by the fact that many tissues contain microvasculature subject to the injuries associated with endothelial dysfunction. In health, the endothelium is a net producer of NO; however, once the eNOS enzyme uncouples it becomes a net producer of ROS, which would promote a positive feedback ROStRAS axis activation. Importantly, eNOS uncoupling occurs early in the progression of CRS and T2DM [36].

Local generation of ROS (vascular injury) could be one of the triggers/instigators or act as a central mechanism of ROS-tRAS axis activation in most organs since the vascular capillary bed is ubiquitous. Further, this mechanism may be responsible for the early findings of pericapillary and perivascular fibrosis in the Ren 2 model of hypertension and insulin resistance, which manifests tissue overexpression of the mouse renin gene [37-40].

\section{Positive Effects of NO on Tissue Remodeling}

Endothelial-derived NO may be considered the quintessential regulator of vascular homeostasis promoting vasodilation of vascular smooth muscle cell(s) (VSMC), counteracting VSMC proliferation and migration, decreasing adhesiveness of the monocytic white blood cells and platelets to the endothelial monolayer, antioxidant effects (via scavenging ROS locally acting as a chain-breaking antioxidant to scavenge ROS) and antifibrotic effects (decreasing the activation of matrix metalloproteinases, which are redox sensitive). Any clinical therapeutic agent that aids in the restoration of vascular eNOS activation and decreases the generation of ROS will assist in the reduction of maladaptive end-organ remodeling and dysfunction, and complications associated with the CRS and T2DM [36].

\section{ROS as a Central Initiator of tRAS Activation: The ROS-tRAS Axis}

There are at least five common mechanisms responsible for generating ROS that may result in the activation of a ROS-tRAS axis: metabolic substrate excess, hormonal excess, hypoxia, injury/trauma, and inflammation may be associated with ROS production (fig. 3).

\section{Metabolic Substrate Excess}

Hyperglycemia-glucotoxicity is a commonly known environment responsible for the production of ROS and activation of the ROS-tRAS axis [30, 36-46]. This environment generates ROS largely by glucose autoxidation and the generation of glycated proteins, including 


\section{CardioRenal Medicine}

advanced glycation end-products (AGE) and RAGE (their receptor), which increase ROS and inactivate and/or deplete essential antioxidant enzymes such as superoxide dismutase, catalase, and uncoupling of the eNOS enzyme [30, 37, 41]. Hyperhomocysteinemia via autoxidation is also capable of generating ROS resulting in ROS-tRAS axis activation [42]. Additionally, xanthine oxidase activation and resulting hyperuricemia may result in the generation of ROS [43] (fig. 3).

\section{Hormonal Excess}

In the CRS, prediabetes and T2DM insulin resistance drive compensatory pancreatic $\beta$ cell-mediated hyperinsulinemia, hyperproinsulinemia, and hyperamylinemia, which act synergistically to activation of a cRAS-tRAS-ROS axis [44-46] (fig. 3).

\section{Hypoxia-Ischemia/Ischemia Reperfusion}

Hypoxia-ischemia/ischemia reperfusion in the pancreas, kidney, heart, and liver are associated with an increase in ROS and activation of the ROS-tRAS axis [47-50] (fig. 3). This excess production of ROS will initiate the abnormalities described previously.

\section{Injury and Trauma}

Injury and trauma, e.g. due to physical, surgical, chemical, and radiation injury, result in TRAS activation and ROS generation, which, in turn, activate the innate wound healing mechanism previously described involving all involved organ systems [51-60] (fig. 3).

\section{Inflammation}

Inflammation and ROS are tightly associated with tissue injury/wounding and there is bidirectional linkage between inflammation and ROS (fig. 3). Bacterial, viral, and parasitic diseases (infectious inflammation) are known to generate large amounts of ROS, which are usually generated via acute inflammatory neutrophilic/oxidative-respiratory bursts. These bursts primarily involve the phagocytic inducible NO synthase enzyme, which produces robust amounts of $\mathrm{NO}$ and injurious peroxynitrite $\left(\mathrm{ONOO}^{-}\right)$. This process also involves $\mathrm{NAD}(\mathrm{P}) \mathrm{H}$ oxidase enzyme activation producing superoxide anion $\left(\mathrm{O}_{2}{ }^{-}-\right.$spontaneously dismutated to $\mathrm{H}_{2} \mathrm{O}_{2}$ ) and myeloperoxidase enzyme producing hypochlorous acid ( $\mathrm{HCLO}^{-}$) to rid the host of offensive invaders. Infectious disease injury then utilizes the innate local tissue wound healing mechanisms for tissue repair, resolution, and recovery (fig. 4). In contrast, the non-infectious immunologic diseases involving antigen-antibody reactions are associated with chronic inflammation involving mononuclear cells: lymphocytes and the monocyte-derived macrophage. Both of these chronic inflammatory cells are known to induce the nuclear transcription factor nuclear factor $\kappa \mathrm{B}(\mathrm{NF} \kappa \mathrm{B})$, which induces the major downstream cytokines tumor necrosis factor- $\alpha$ (TNF- $\alpha$ ) and interleukin-1 $\beta$ (IL-1 $\beta$ ) plus a host of cytokines, chemokines, cellular adhesion molecules, and monocyte chemoattractant proteins [61]. Likewise, the cytokines TNF- $\alpha$ and IL-1 $\beta$ can activate NFKB via redox-sensitive mechanisms. Each of these five mechanisms plays an important role in the activation of the ROStRAS axis in local tissues and organ systems (fig. 3).

\section{Involvement of tRAS in Organs Involved in CRS and T2DM Development}

\section{SkM Tissue and Insulin Resistance}

SkM accounts for $80-90 \%$ of insulin-stimulated glucose disposal and is the primary tissue responsible for peripheral insulin sensitivity and glucose homeostasis [62]. Remodeling of SkM (including capillary rarefaction, mitochondrial loss, and intermyofibrillar lipid de- 


\section{CardioRenal Medicine}

position) is involved early in the development of the CRS and T2DM [63]. Additionally, it is known that CRS and T2DM are associated with polygenic and environmental etiologies (including excess compact calories, physical inactivity, and obesity). Further, SkM insulin resistance is a prelude and fundamental to the development of CRS and T2DM [64, 65]. Importantly, tRAS is activated in SkM of patients with the CRS and T2DM [62-66].

\section{Adipose Tissue and Insulin Resistance}

The obesity epidemic is the driving force behind the development of insulin resistance and the components of the CRS. Obesity develops due to an interaction between polygenic and environmental excess such as overnutrition and sedentary lifestyles. It arises from increased size (lipid-loading hypertrophy) and increased numbers of adipocytes (hyperplasia) from the differentiation of adipose precursor cells (preadipocytes) to mature adipocytes utilizing the appropriate nutritional and hormonal signals [67-69].

A local tRAS exists in adipose tissue $[15,70]$, and its components have increased expression in obese adipose tissue in humans. AngII markedly inhibits adipogenic differentiation of human adipocytes via $\mathrm{AT}_{1} \mathrm{R}$, and this differentiation is inversely correlated with insulin sensitivity [71]. RAS blockade may even delay the onset of T2DM by promoting the differentiation of adipocytes into mature adipocytes and thus decrease the deposition of toxic ectopic lipids in non-adipose tissues such as SkM, liver, and even the pancreatic islets, resulting in improved $\beta$-cell function [71].

Histological studies of adipose tissue in obesity states indicate the presence of inflammatory cells consisting primarily of macrophages; however, mast cells (MC; containing both renin and chymase) may also be found in this adipose tissue (fig. 5). These cells may contribute to the increased systemic inflammation that has been proposed to participate in the development of insulin resistance, CRS, T2DM, and the affected end-organs [72]. Recent investigations have led to a new paradigm, which recognizes that obesity may be considered a lowgrade inflammatory disease. In this context, obesity without inflammation may not result in insulin resistance [73]. With the findings of increased tRAS and inflammation in adipose tissue, it is not surprising that fibrosis of the interstitial vascular stromal-supporting ECM has been demonstrated in humans and animal models such as the Zucker obese ( $f a / f a)$ and Zucker diabetic fatty rat models [73]. Further, fibrosis in adipose tissue of obese patients with calcific uremic arteriolopathy-calciphylaxis (an increasingly reported condition found primarily in patients with end-stage renal disease on dialysis) may contribute to the increased subdermal adipose tissue necrosis and non-healing skin ulcerations [74, 75]. Replacement fibrosis is less compliant and associated with increased stiffness of collagen and the stromal vascular matrix, which may decrease the capability of the microcirculation to properly dilate when appropriately signaled [74]. Importantly, adipose tissue fibrosis may be more than a reparative response to local tissue injury as it may contribute to the resistance of weight loss if the obesity has been present for prolonged periods. This fibrosis could result in loss of cell-cell and cell-matrix communication connections in adipose tissue, which could interfere with cellular signaling processes regulating adipogenesis and metabolic functions [70-75].

\section{Hepatic Tissue and Insulin Resistance - Metabolic Hepatopathy}

Insulin is known to have suppressive effects on glucose production by its direct effects on hepatocytes and indirect effects involving suppression of adipose tissue lipolysis with reductions in free fatty acids (FFA) [64, 76]. Thus, insulin resistance results in increased gluconeogenesis and increased lipolysis resulting in increased glucose and FFA. Hepatic tissue insulin resistance plays an important role early on in the development of CRS and T2DM. Similar to the other organ tissues discussed in this section, the liver may also be abnormally affected by CRS and T2DM due to the multiple metabolic toxicities with the development of 


\section{CardioRenal Medicine}

Cardiorenal Med 2011;1:193-210

DOI: 10.1159/000329926

Published online: July 30, 2011

Hayden et al.: Mechanisms of Local tRAS Activation (c) 2011 S. Karger AG, Basel www.karger.com/crm
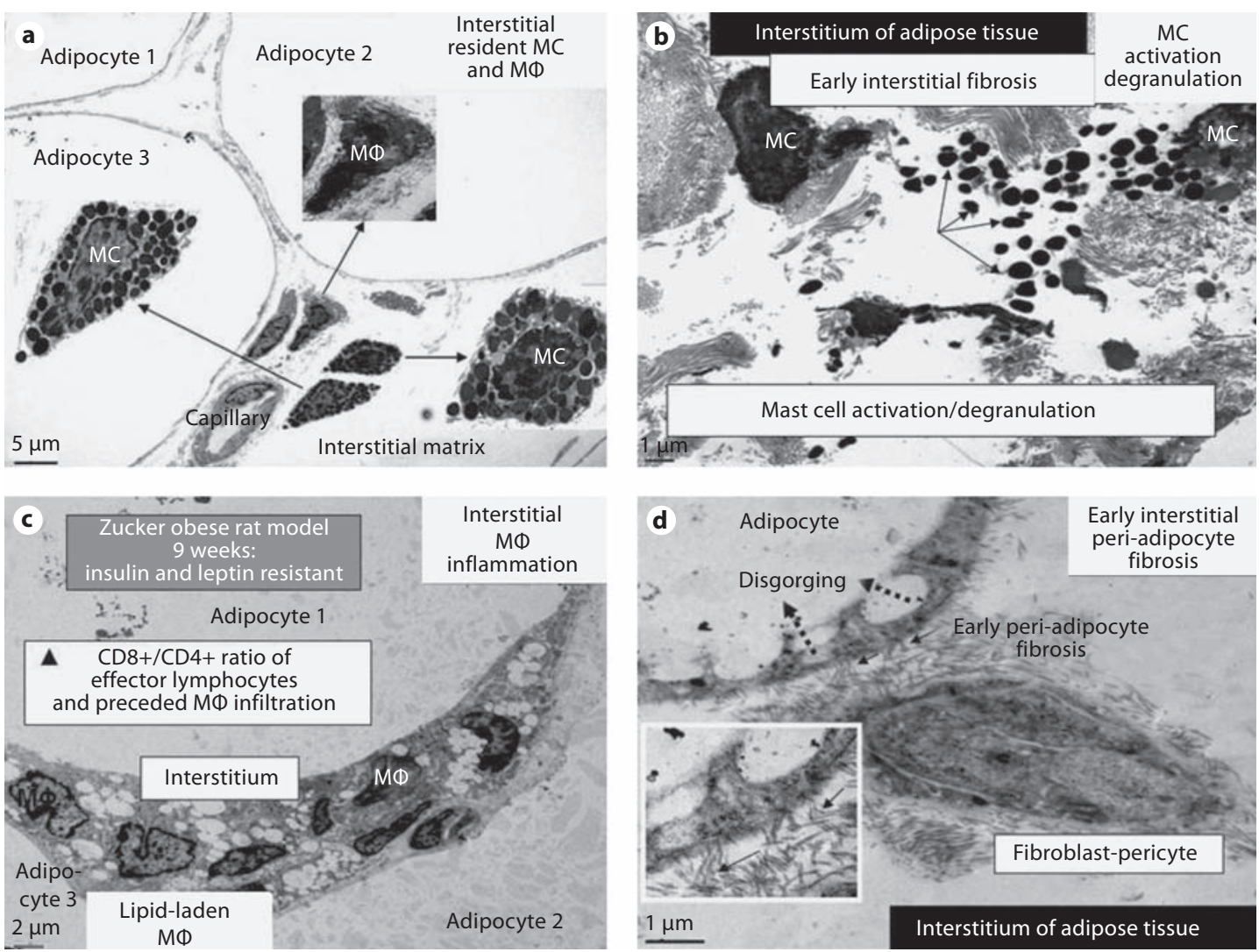

Fig. 5. MC activation and degranulation with associated inflammation and fibrosis in adipose tissue of Zucker obese $(\mathrm{fa} / \mathrm{fa}$ ) rats at 9 weeks of age. The presence of $\mathrm{MC}$ in the interstitium of the obese subcutaneous and visceral adipose tissue in the young Zucker $(\mathrm{fa} / \mathrm{fa}$ ) model of obesity and insulin resistance with CRS and impaired glucose tolerance at 9 weeks of age $(\mathbf{a} \times 300$; bar $=5 \mu \mathrm{m})$ with associated inflammation and fibrosis. None of these observations was noted in the Zucker lean littermates. $\mathbf{b}$ MC activation and degranulation. Note the numerous liberated highly-electron-dense free MC secretory granules in the interstitium (arrows). $\times 1,000$; bar $=1 \mu \mathrm{m}$. c The ensuing chronic inflammation with numerous lipid-laden macrophages $(\mathrm{M} \Phi)$ in the interstitium of the omental adipose tissue. $\times 500$; bar $=2 \mu \mathrm{m}$. $\mathbf{d}$ The ensuing early peri-adipocyte fibrosis (solid arrows) that progresses with continued chronic injury and the wound healing response. Note the disgorging of cytoplasmic lipid vacuoles into the large lipid-laden granule of the adipocyte (dotted arrows). Exploded inset depicts a higher magnification of collagen adhering to the adipocyte (arrows). There also exists pericapillary fibrosis (not shown). $\times 3,000$; bar $=1 \mu \mathrm{m}$. In the past, we have thought classically that the fibroblast was important for fibrosis, however we are constantly learning that the pericyte is also capable of synthesizing collagen and that pericytes can differentiate into fibroblast-myofibroblast cell types. We currently speculate that this direct adherence (direct cell-matrix interaction) of collagen to the adipocyte (peri-adipocyte fibrosis) may result in a relative inability of adipocytes to undergo delipidation.

non-alcoholic fatty liver disease or non-alcoholic steatohepatitis. Non-alcoholic fatty liver disease represents a spectrum of fatty liver disorders with evolving remodeling changes ranging from hepatic steatosis to non-alcoholic steatohepatitis, fibrosis, cryptogenic cirrhosis, and end-stage liver disease [76-80].

The initial cellular remodeling consists of the intracellular hepatocyte accumulation of fat due to increased lipolysis and excessive generation of triglycerides and FFA. This intracellular accumulation of fat is associated with enhanced oxidative stress and ROS generation within the hepatocytes, while setting in motion a panoply of metabolic and intra-/extracel- 


\section{CardioRenal Medicine}

lular remodeling events within the liver. A 'two-hit' model has been proposed regarding the progression of non-alcoholic fatty liver disease, with the first hit being the obesity related to the CRS leading to the development of steatosis, and the second hit being hepatocyte injury, inflammation (primarily the macrophage), and fibrosis with the best candidates for the second hit being oxidative stress and increased production of cytokines (primarily TNF- $\alpha$ ) [80, 81]. The hepatic stellate cell (a sinusoidal pericyte cell) is central to the underlying ECM accumulation and fibrosis. As a stellate-pericyte cell, it initially begins laying down ECM (types I and III collagen) adjacent to the hepatic sinusoids and may be responsible for a sinusoidal/ endothelial cell-hepatocyte structural and functional uncoupling. There is evidence of an activated local tRAS in liver fibrosis [19]. Recent publications have demonstrated the attenuation of increased levels of AngII, oxidative stress, steatosis, inflammation, and fibrosis with the use of RAS blockade and antioxidants [82-84].

\section{Endocrine Pancreatic Tissue}

The pancreatic islet tissue is now known to harbor a full complement of the RAS in addition to the exocrine pancreas and, importantly, this tRAS becomes activated in the CRS and T2DM $[18,85,86]$.

The endocrine islet and $\beta$-cell are affected by the early development of insulin resistance in the obese adipose tissue, SkM and hepatic tissues in the development of CRS and T2DM. In response to systemic insulin resistance, there is an initial compensatory hyperinsulinemia, hyperproinsulinemia, and hyperamylinemia by the islet $\beta$-cell to overcome this resistance and contribute to the activation of both systemic cRAS and local tRAS [44-46, 64]. Additionally, increased levels of islet ROS as a result of increased ROS production from multiple metabolic toxicities may be associated with a ROS-tRAS axis activation. These redox injuries and the wounded islet could then set in motion the islet wound healing response, which results in peri-islet-islet exocrine interface inflammation involving the macrophage and pericyte hyperplasia resulting in an attenuation of communication between the islet and exocrine pancreas [35]. Early on, the $\beta$-cell begins to dysfunction due to the multiple metabolic toxicities and later fails due to $\beta$-cell apoptosis. The resulting hyperglycemia and subsequent glucotoxicity (glucose autoxidation, glycated proteins, and AGE) with associated ROS generation would become the driving force behind islet tRAS activation. This persistent activation of tRAS-ROS generation/injury within the islet would further instigate an ongoing wound healing response mechanism (fig. 4). These multiple complex interactions with islet wounding would result in a chronic injury process resulting in intra- and peri-islet fibrosis [30]. Additionally, the earlier amyloidogenic islet amyloid amylin (islet amyloid polypeptide) would be hypersecreted (hyperamylinemia) in a redox-sensitive oxidative stress milieu. These structural cellular and ECM remodeling processes contribute greatly along with $\beta$-cell apoptosis to not only progress to a prediabetes stage but also to overt T2DM and - if not aggressively controlled - to exogenous insulin replacement therapy [30, 87-94]. Islet fibrosis and amylin-derived islet amyloid deposition may serve as a barrier to nutrient/toxic metabolic products, which contributes to the development of a barrier to insulin diffusion from the $\beta$-cell to the systemic microcirculation; however, this has yet to be fully investigated except for preliminary ultrastructural studies. Importantly, improved functional islet response has been found to be associated with the structural improvement in ECM fibrosis remodeling with the use of RAS blockade in the Zucker model of T2DM [95]. Zucker obese models of insulin resistance have demonstrated the ultrastructural findings of pericapillary fibrosis as early as 14 weeks of age. In addition to islet fibrosis and islet amyloid deposition, there is the deposition of adipose tissue within the islet and exocrine pancreas in humans. The functional and structural changes within the islet result in $\beta$-cell dysfunction and apoptotic failure demonstrating the important role of the ROS-tRAS axis activation. 


\section{CardioRenal Medicine}

\begin{tabular}{l}
\hline Cardiorenal Med 2011;1:193-210 \\
\hline $\begin{array}{l}\text { DOI: 10.1159/000329926 } \\
\text { Published online: July 30, } 2011\end{array}$ \\
\hline Hayden et al.: Mechanisms of Local tRAS Activation \\
www.karger.com/crm
\end{tabular}

\section{Differential Regulation and Sequestration of tRAS Components in CRS and T2DM}

In some circumstances, injured organs have not been shown conclusively to activate a full complement of RAS components necessary to result in the generation of AngII. Herein lies the construct of the interaction between the cRAS and tRAS. A classic example of this scenario occurs in the myocardium where it is unclear if renin is capable of being synthesized or upregulated within the myocardium [96]. Even if the full complement of tRAS components cannot be generated in injured organs or tissues in sufficient amounts, there is the potential of injured organs to have previously sequestered these components and therefore effectively generate the effector peptide AngII [10]. Importantly, as can be noted in figures 5 and 6, macrophages and MC are also capable of providing a full RAS complement as the inflammatory phase of the local tissue wound healing process proceeds. Our group often refers to the 'pump-primer effect' of renin regarding the supply of intermittent renin to local tissues as only intermittent small amounts of cRAS renin may be required to instigate the activated tRAS-AngII-generating system in addition to possible sequestration of circulating renin or other missing components of tRAS.

\section{Importance of Profibrotic Aldosterone and Endothelin-1}

Importantly, aldosterone and endothelin-1 (ET-1), activated via the RAS, are involved in this ongoing fibrosis. Aldosterone is synthesized primarily in the adrenal cortical zona glomerulosa cells, and its synthesis and secretion are activated by AngII and possibly ET-1 [97]. In addition to the mineralocorticoid effects, there are profibrotic effects of aldosterone. Both aldosterone and ET- 1 activate transforming growth factor $\beta-1$ (TGF $\beta-1)$ and connective tissue growth factor-1 [98]. The 21-amino-acid peptide ET-1 is synthesized primarily by the endothelial cell and is the most potent human vasoconstrictor known. ET-1 is activated by AngII via $\mathrm{AT}_{1} \mathrm{R}$ and is capable of turning on the transcription of the preproET-1 gene via activation of the phospholipase $\mathrm{C}$ and protein kinase $\mathrm{C}$ pathways [99].

The myocardial fibrotic aspects of aldosterone have been shown to be abrogated in the Ren 2 transgenic rat model by treatment with a subpressor dose of the mineralocorticoid antagonist spironolactone [37]. Additionally, in a postmyocardial infarction model in the rat, it has been demonstrated that an ET-1 antagonist (bosentan) had a positive effect on survival, hemodynamics, and myocardial ECM remodeling fibrosis [99]. In clinical trials, the Randomized Aldactone Evaluation Study (RALES), the mineralocorticoid receptor antagonist spironolactone was shown to reduce mortality by $30 \%$ without affecting blood pressure in patients with NYHA class III and IV [100]. Likewise, for postmyocardial infarction heart failure patients in the Eplerenone in Patients with Heart Failure due to Systolic Dysfunction (EPHESUS) trial, the more specific aldosterone antagonist eplerenone proved to reduce total mortality by $26 \%$ [101]. In summary, there is a definite interaction between ET-1, aldosterone, and the ROS-tRAS axis [97].

\section{Novel RAS Components}

Novel RAS components that may add to our understanding of both cRAS and tRAS have been discovered in recent years. These include ACE2, AngIII, AngIV, Ang(1-7), Mas receptor, prorenin, and preprorenin and its renin receptor (fig. 2). While important, an individual discussion of each of these novel components is beyond the scope of this review. As we learn more about each of these novel additions, we will be able to better understand the cRAS and tRAS axes [102]. 


\section{CardioRenal Medicine}

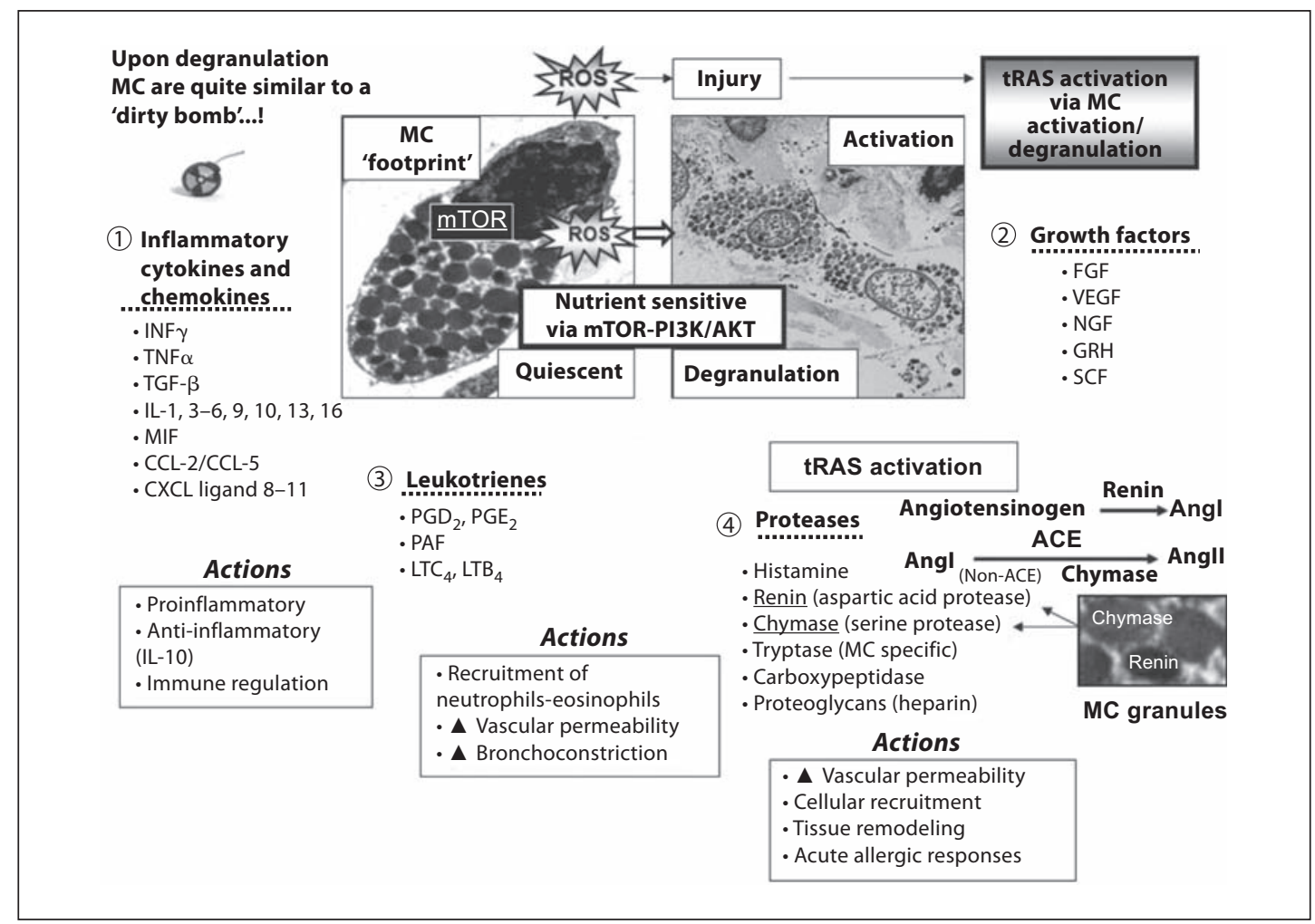

Fig. 6. Local injury to tissues due to ROS results in resident MC activation and degranulation: mediator release and actions. These events, in turn, may result in local tRAS activation resulting in local wound healing mechanisms and resultant tissue maladaptive remodeling with excessive fibrosis and scarring to the tissues with loss of function. Upon activation and degranulation the MC secretes and releases a plethora of active soluble mediators which include inflammatory cytokines and chemokines (1), growth factors (2), leukotrienes (3), and proteases (4). These mediators are responsible for numerous actions: inflammatory and immune regulation, cellular recruitment of inflammatory cells, increased vascular permeability, bronchoconstriction, acute allergic responses, and importantly cellular and ECM remodeling. Activation of tRAS via MC activation and degranulation allow for an increase in proteases, specifically the aspartic acid protease renin and the serine protease chymase, an enzyme important for the activation of a local tRAS, which in turn accelerates local tissue ECM accumulation, fibrosis, and scarring. AKT = Protein kinase B; CCL-2, $-5=\mathrm{C}-\mathrm{C}$ motif ligand; CXCL $=\mathrm{C}-\mathrm{X}-\mathrm{C}$ motif ligand; FGF $=$ fibroblast growth factor; GMCST = granulocyte macrophage-colony stimulating factor; $\mathrm{GRH}=$ gonadotrophin-releasing hormone; INF $\gamma=$ interferon $\gamma ; \mathrm{LTB}_{4} / \mathrm{LTC}_{4}=$ leukotriene $\mathrm{B}_{4} / \mathrm{C}_{4} ; \mathrm{MIF}=$ macrophage-inhibitory factor; $\mathrm{mTOR}=$ mammalian target of rapamycin; $\mathrm{NGF}=$ nerve growth factor; $\mathrm{PAF}=$ platelet-activating factor; $\mathrm{PGD}_{2} / \mathrm{PGE}_{2}=$ prostaglandin $\mathrm{D}_{2} / \mathrm{E}_{2} ; \mathrm{PI} 3 \mathrm{~K}=$ phosphoinositide 3 -kinase; $\mathrm{SCF}=$ stem cell factor; VEGF = vascular endothelial growth factor.

\section{Emerging Role of the MC in Inflammation, tRAS Activation, and Fibrosis}

Classically, the MC has been related to allergic diseases and responses; however, recent evidence indicates that MC may also contribute to other diseases such as rheumatoid arthritis, cardiovascular disease, atherosclerosis, vascular aneurysms, cancer, and multiple sclerosis $[103,104]$. Resident MC within the ECM are known to synthesize and secrete two important proteases (the aspartic acid protease renin and non-ACE pathway serine protease enzyme chymase), which are important in the generation of AngII at the local tissue level (fig. 5, 6). When tissue injury occurs, MC undergo activation and degranulation, which supplies the 


\section{CardioRenal Medicine}

necessary protease substrates (renin and chymase) allowing a local tRAS to be activated (fig. 4-6) [105, 106]. Importantly, the nutrient sensor mTOR (mammalian target of rapamycin receptor) not only links obesity and insulin resistance with CRS, via a nutrient excess pathway mTOR signaling may also regulate innate inflammatory responses [106, 107]. Interestingly, the discovery that deficiency in or pharmacological stabilization of MC reduced diet-induced obesity and diabetes in mice has definitely highlighted the importance of the MC in obesity, insulin resistance, CRS, and T2DM in humans and may be of high importance [103]. MC activation and degranulation is important in activating the inflammatory response with subsequent fibrosis, and may be directly involved in the nutrient excess associated with the obesity epidemic and its relation to ROS, tissue injury, and the association of obesity with the CRS and T2DM [108].

\section{Discussion and Perspectives}

While the activation of the cRAS has been extensively studied and well accepted, the importance of tRAS is somewhat nascent. We have reviewed some of the possible mechanisms responsible for tRAS activation in the CRS and T2DM. Furthermore, we have elected to use the mechanism of tissue/organ injury, redox stress-ROS generation, the ROS-tRAS axis, and the innate wound healing response paradigm to better understand the mechanisms of tRAS activation.

tRAS is increasingly recognized as an important element of tissue injury and remodeling, and acts in concert with cRAS as well as independently of cRAS [6,9]. While the concepts presented in this discussion definitely support a central role for RAS blockade in the treatment of CRS and T2DM, it can be noted that the clinician must additionally utilize a global risk reduction concept in order to decrease the excessive activation of tRAS/AngIIgenerating system $[43,44,77,87]$.

Human and animal models of CRS display activation of a local tRAS and increases in ROS in each of the end-organs affected by this syndrome. Therefore, we have attempted to present a unifying mechanism of how a local tRAS may be activated in those organs that are importantly involved in the development of the CRS and T2DM (fig. 3, 4). By limiting our discussion to these particular end-organs, we did not go into any in-depth discussion of the cardiovascular system, retina, neuronal systems (brain or peripheral neuronal unit), kidney or ovary. The following references may be helpful to those who wish to learn more about those end-organ systems that were not included in this discussion [30, 39, 40, 109117].

\section{Acknowledgment}

The authors would like to acknowledge Drs. James O. Davis and John H. Laragh for their life-long efforts in unraveling and delineating the RAS functions. The authors also acknowledge the mentorship and support of Dr. Tomas Burns. Finally, we acknowledge Brenda Hunter for her editorial assistance.

\section{Disclosure Statement}

This research was supported by NIH (R01 HL73101-01A1) and Veterans Affairs Merit System (0018; NSF LP) and Veterans Affairs Grants (J.R.S. and A.W.-C.). 


\section{CardioRenal Medicine}

\begin{tabular}{l|l}
\hline Cardiorenal Med 2011;1:193-210 \\
\hline $\begin{array}{l}\text { DOI: 10.1159/000329926 } \\
\text { Published online: July 30, 2011 }\end{array}$ & $\begin{array}{l}\text { @ 2011 S. Karger AG, Basel } \\
\text { www.karger.com/crm }\end{array}$ \\
\hline
\end{tabular}

\section{References}

1 Basso N, Terragno NA: History about the discovery of the renin-angiotensin system. Hypertension 2001;38:12461249.

2 Dietze GJ, Henriksen EJ: Angiotensin-converting enzyme in skeletal muscle: sentinel of blood pressure control and glucose homeostasis. J Renin Angiotensin Aldosterone Syst 2008;9:75-88.

-3 Célérier J, Schmid G, Le Caer JP, Gimenez-Roqueplo AP, Bur D, Friedlein A, Langen H, Corvol P, Jeunemaitre X: Characterization of a human angiotensinogen cleaved in its reactive center loop by a proteolytic activity from Chinese hamster ovary cells. J Biol Chem 2000;275:10648-10654.

-4 Imai T, Miyazaki H, Hirose S, Hori H, Hayashi T, Kageyama R, Ohkubo H, Nakanishi S, Murakami K: Cloning and sequence analysis of cDNA for human renin precursor. Proc Natl Acad Sci USA 1983;80:7405-7409.

5 Lanzillo JJ, Stevens J, Dasarathy Y, Yotsumoto H, Fanburg BL: Angiotensin-converting enzyme from human tissues. Physicochemical, catalytic, and immunological properties. J Biol Chem 1985;260:14938-14944.

6 Paul M, Poyan Mehr A, Kreutz R: Physiology of local renin-angiotensin systems. Physiol Rev 2006;86:747-803.

7 Paul M, Bachmann J, Ganten D: The tissue renin-angiotensin systems in cardiovascular disease. Trends Cardiovasc Med 1992;2:94-99.

8 Campbell DJ: Tissue renin-angiotensin system: sites of angiotensin formation. J Cardiovasc Pharmacol 1987;10(suppl 7):S1-S8.

-9 Lindpaintner K, Ganten D: Tissue renin-angiotensin systems and their modulation: the heart as a paradigm for new aspects of converting enzyme inhibition. Cardiology 1991;79(suppl 1):32-44.

10 Dzau VJ, Re R: Tissue angiotensin system in cardiovascular medicine. A paradigm shift? Circulation 1994;89:493498.

11 Dzau VJ: Circulating versus local renin-angiotensin system in cardiovascular homeostasis. Circulation 1988;77(6 Pt 2):I3-I14

12 Johnston CI: Franz Volhard Lecture. Renin-angiotensin system: a dual tissue and hormonal system for cardiovascular control. J Hypertens Suppl 1992;10:S13-S26.

13 Kumar R, Singh VP, Baker KM: The intracellular renin-angiotensin system: a new paradigm. Trends Endocrinol Metab 2007;18:208-214.

14 Sharma AM, Engeli S: The role of renin-angiotensin system blockade in the management of hypertension associated with the cardiometabolic syndrome. J Cardiometab Syndr 2006;1:29-35.

15 Engeli S, Negrel R, Sharma AM: Physiology and pathophysiology of the adipose tissue renin-angiotensin system. Hypertension 2000;35:1270-1277.

16 Montgomery H, Humphries SE, Leung PS: Renin-angiotensin system: the new frontier. Int J Biochem Cell Biol 2003; 35:758.

17 Lau T, Carlsson PO, Leung PS: Evidence for a local angiotensin-generating system and dose-dependent inhibition of glucose-stimulated insulin release by angiotensin II in isolated pancreatic islets. Diabetologia 2004;47:240-248.

18 Leung PS: The physiology of a local renin-angiotensin system in the pancreas. J Physiol 2007;580:31-37.

19 Lubel JS, Herath CB, Burrell LM, Angus PW: Liver disease and the renin-angiotensin system: recent discoveries and clinical implications. J Gastroenterol Hepatol 2008;23:1327-1338.

20 Savaskan E: The role of the brain renin-angiotensin system in neurodegenerative disorders. Curr Alzheimer Res 2005; 2:29-35.

21 McKinley MJ, Albiston AL, Allen AM, Mathai ML, May CN, McAllen RM, Oldfield BJ, Mendelsohn FAO, Chai SY: The brain renin-angiotensin system: location and physiological roles. Int J Biochem Cell Biol 2003;35:901-918.

-22 Higashimori K, Gante J, Holzemann G, Inagami T: Significance of vascular renin for local generation of angiotensins. Hypertension 1991;17:270-277.

23 Carey RM, Siragy HM: Newly recognized components of the renin-angiotensin system: potential roles in cardiovascular and renal regulation. Endocr Rev 2003;24:261-271.

24 Peters H, Unger T: Mast cells and the power of local RAS activation. Nephrol Dial Transplant 2007;22:40-42.

25 Jin M, Wilhelm MJ, Lang RE, Unger T, Lindpaintner K, Ganten D: Endogenous tissue renin-angiotensin systems. From molecular biology to therapy. Am J Med 1988;84:28-36.

-26 Cooper ME: The role of the renin-angiotensin-aldosterone system in diabetes and its vascular complications. Am J Hypertens 2004;17(11 Pt 2):16S-20S.

27 Wookey PJ, Cao Z, Cooper ME: Interaction of the renal amylin and renin-angiotensin systems in animal models of diabetes and hypertension. Miner Electrolyte Metab 1998;24:389-399.

28 Bachmann S, Peters J, Engler E, Ganten D, Mullins J: Transgenic rats carrying the mouse renin gene - morphological characterization of a low-renin hypertension model. Kidney Int 1992;41:24-36.

29 Hayden MR, Karuparthi PR, Habibi J, Wasekar C, Lastra G, Manrique C, Stas S, Sowers JR: Ultrastructural islet study of early fibrosis in the Ren2 rat model of hypertension. Emerging role of the islet pancreatic pericyte-stellate cell. JOP 2007;8:725-738.

- 30 Hayden MR, Sowers JR: Isletopathy in type 2 diabetes mellitus: implications of islet RAS, islet fibrosis, islet amyloid, remodeling, and oxidative stress. Antioxid Redox Signal 2007;9:891-910.

- 31 Ganten D, Marquez-Julio A, Granger P, Hayduk K, Karsunky KP, Boucher R, Genest J: Renin in the dog brain. Am J Physiol 1971;221:1733-1737. 


\section{CardioRenal Medicine}

Cardiorenal Med 2011;1:193-210

\begin{tabular}{l|l}
\hline DOI: 10.1159/000329926 & ( 2011 S. Karger AG, Basel
\end{tabular}

Published online: July 30, 2011

Hayden et al.: Mechanisms of Local tRAS Activation www.karger.com/crm

32 Miyata K, Ohashi N, Suzaki Y, Katsurada A, Kobori H: Sequential activation of the reactive oxygen species/angiotensinogen/renin-angiotensin system axis in renal injury of type 2 diabetic rats. Clin Exp Pharmacol Physiol 2008;35: 922-927.

33

$>34$

$>35$

Clark RA: Cutaneous tissue repair: basic biologic considerations. J Am Acad Dermatol 1985;13(5 Pt 1):701-725.

Clark RA: The commonality of cutaneous wound repair and lung injury. Chest 1991;99(3 suppl):57S-60S.

Hayden MR, Patel K, Habibi J, Gupta D, Tekwani SS, Whaley-Connell A, Sowers JR: Attenuation of endocrine-exocrine pancreatic communication in type 2 diabetes: pancreatic extracellular matrix ultrastructural abnormalities. J Cardiometab Syndr 2008;3:234-243.

$>36$ Hayden MR, Tyagi SC: Is type 2 diabetes mellitus a vascular disease (atheroscleropathy) with hyperglycemia a late manifestation? The role of NOS, NO, and redox stress. Cardiovasc Diabetol 2003;2:2.

-37 Habibi J, Whaley-Connell A, Hayden MR, DeMarco VG, Schneider R, Sowers SD, Karuparthi P, Ferrario CM, Sowers JR: Renin inhibition attenuates insulin resistance, oxidative stress, and pancreatic remodeling in the transgenic Ren2 rat. Endocrinology 2008;149:5643-5653.

-38 Stas S, Whaley-Connell A, Habibi J, Appesh L, Hayden MR, Karuparthi PR, Qazi M, Morris EM, Cooper SA, Link CD, Stump C, Hay M, Ferrario C, Sowers JR: Mineralocorticoid receptor blockade attenuates chronic overexpression of the renin-angiotensin-aldosterone system stimulation of reduced nicotinamide adenine dinucleotide phosphate oxidase and cardiac remodeling. Endocrinology 2007;148:3773-3780.

-39 Lastra G, Whaley-Connell A, Manrique C, Habibi J, Gutweiler AA, Appesh L, Hayden MR, Wei Y, Ferrario C, Sowers JR: Low-dose spironolactone reduces reactive oxygen species generation and improves insulin-stimulated glucose transport in skeletal muscle in the TG(mRen2)27 rat. Am J Physiol Endocrinol Metab 2008;295:E110-E116.

-40 Hayden MR, Chowdhury N, Govindarajan G, Karuparthi PR, Habibi J, Sowers JR: Myocardial myocyte remodeling and fibrosis in the cardiometabolic syndrome. J Cardiometab Syndr 2006;1:326-333.

41 Hayden MR, Tyagi SC: Intimal redox stress: accelerated atherosclerosis in metabolic syndrome and type 2 diabetes mellitus. Atheroscleropathy. Cardiovasc Diabetol 2002;1:3.

42 Hayden MR, Tyagi SC: Homocysteine and reactive oxygen species in metabolic syndrome, type 2 diabetes mellitus, and atheroscleropathy: the pleiotropic effects of folate supplementation. Nutr J 2004;3:4.

43 Hayden MR, Tyagi SC: Uric acid: a new look at an old risk marker for cardiovascular disease, metabolic syndrome, and type 2 diabetes mellitus: the urate redox shuttle. Nutr Metab (Lond) 2004;1:10.

-44 Hayden MR, Sowers JR: Hypertension in type 2 diabetes mellitus. Insulin 2006;1:22-37.

45 Hayden MR, McGowan BS: Understanding the links between insulin resistance, diabetes, and cardiovascular risk. Practical Diabetol 2005;24:6-14.

-46 Hayden MR, Whaley-Connell A, Sowers JR: Role of angiotensin II in diabetic cardiovascular and renal disease. Curr Opin Endocrinol Diabetes 2006;13:135-140.

47 Chan WP, Fung ML, Nobiling R, Leung PS: Activation of local renin-angiotensin system by chronic hypoxia in rat pancreas. Mol Cell Endocrinol 2000;160:107-114.

48 Nangaku M, Fujita T: Activation of the renin-angiotensin system and chronic hypoxia of the kidney. Hypertens Res 2008;31:175-184.

49 Matoba S, Tatsumi T, Natsuya Keira N, Kawahara A, Akashi K, Kobara M, Asayama J, Nakagawa M: Cardioprotective effect of angiotensin-converting enzyme inhibition against hypoxia/reoxygenation injury in cultured rat cardiac myocytes. Circulation 1999;99:817-822.

50 Guo L, Richardson KS, Tucker LM, Doll MA, Hein DW, Arteel GE: Role of the renin-angiotensin system in hepatic ischemia reperfusion injury in rats. Hepatology 2004;40:583-589.

51 Gorbunov NV, Elsayed NM, Kisin ER, Kozlov AV, Kagan VE: Air blast-induced pulmonary oxidative stress: interplay among hemoglobin, antioxidants, and lipid peroxidation. Am J Physiol 1997;272:L320-L334.

-52 Järvinen TA, Järvinen TL, Kääriäinen M, Kalimo H, Järvinen M: Muscle injuries: biology and treatment. Am J Sports Med 2005;33:745-764.

-53 Tavazzi B, Vagnozzi R, Signoretti S, Amorini AM, Belli A, Cimatti M, Delfini R, Di Pietro V, Finocchiaro A, Lazzarino G: Temporal window of metabolic brain vulnerability to concussions: oxidative and nitrosative stresses - part II. Neurosurgery 2007;61:390-395, discussion 395-396.

54 Tsuchiya M, Sato EF, Inoue M, Asada A: Open abdominal surgery increases intraoperative oxidative stress: can it be prevented? Anesth Analg 2008;107:1946-1952.

-55 Glantzounis GK, Tselepis AD, Tambaki AP, Trikalinos TA, Manataki AD, Galaris DA, Tsimoyiannis EC, Kappas AM: Laparoscopic surgery-induced changes in oxidative stress markers in human plasma. Surg Endosc 2001;15: 1315-1319.

56 Ohta Y, Kongo-Nishikawa M, Imai Y, Kishikawa T: Contribution of xanthine oxidase-derived oxygen free radicals to the development of carbon tetrachloride-induced acute liver injury in rats. J Clin Biochem Nutr 2003;33:89-93.

57 Sakurai K, Katoh M, Someno K, Fujimoto Y: Apoptosis and mitochondrial damage in INS-1 cells treated with alloxan. Biol Pharm Bull 2001;24:876-882.

58 Turk J, Corbett JA, Ramanadham S, Bohrer A, McDaniel ML: Biochemical evidence for nitric oxide formation from streptozotocin in isolated pancreatic islet. Biochem Biophys Res Commun 1993;197:1458-1464.

59 Zhao W, Diz DI, Robbins ME: Oxidative damage pathways in relation to normal tissue injury. Br J Radiol 2007;80:S23S31. 


\section{CardioRenal Medicine}

\begin{tabular}{l|l}
\hline Cardiorenal Med 2011;1:193-210 \\
\hline $\begin{array}{l}\text { DOI: 10.1159/000329926 } \\
\text { Published online: July 30, } 2011\end{array}$ & $\begin{array}{l}\text { @ 2011 S. Karger AG, Basel } \\
\text { www.karger.com/crm }\end{array}$ \\
\hline
\end{tabular}

Hayden et al.: Mechanisms of Local tRAS Activation

-60 Robbins ME, Diz DI: Pathogenic role of the renin-angiotensin system in modulating radiation-induced late effects. Int J Radiat Oncol Biol Phys 2006;64:6-12.

61 Gloire G, Legrand-Poels S, Piette J: NF-kB activation by reactive oxygen species: fifteen years later. Biochem Pharmacol 2006;72:1493-1505.

62 DeFronzo RA, Gunnarsson R, Björkman O, Olsson M, Wahren J: Effects of insulin on peripheral and splanchnic glucose metabolism in noninsulin-dependent (type II) diabetes mellitus. J Clin Invest 1985;76:149-155.

-63 Lillioja S, Young AA, Culter CL, Ivy JL, Abbott WG, Zawadzki JK, Yki-Järvinen H, Christin L, Secomb TW, Bogardus C: Skeletal muscle capillary density and fiber type are possible determinants of in vivo insulin resistance in man. J Clin Invest 1987;80:415-424.

64 DeFronzo RA: Lilly lecture 1987. The triumvirate: beta-cell, muscle, liver. A collusion responsible for NIDDM. Diabetes 1988;37:667-687.

65 Nistala R, Stump CS: Skeletal muscle insulin resistance is fundamental to the cardiometabolic syndrome. J Cardiometab Syndr 2006;1:47-52.

-66 Agoudemos MM, Greene AS: Localization of the renin-angiotensin system components to the skeletal muscle microcirculation. Microcirculation 2005;12:627-636.

67 Faust IM, Johnson PR, Stern JS, Hirsch J: Diet-induced adipocyte number increase in adult rats: a new model of obesity. Am J Physiol 1978;235:E279-E286.

68 Klyde BJ, Hirsch J: Increased cellular proliferation in adipose tissue of adult rats fed a high-fat diet. J Lipid Res 1979; 20:705-715.

69 Klyde BJ, Hirsch J: Isotopic labeling of DNA in rat adipose tissue: evidence for proliferating cells associated with mature adipocytes. J Lipid Res 1979;20:691-704.

70 Goossens GH, Blaak EE, van Baak MA: Possible involvement of the adipose tissue renin-angiotensin system in the pathophysiology of obesity and obesity-related disorders. Obes Rev 2003;4:43-55.

71 Sharma AM, Janke J, Gorzelniak K, Engeli S, Luft FC: Angiotensin blockade prevents type 2 diabetes by formation of fat cells. Hypertension 2002;40:609-611.

-72 Darimont C, Avanti O, Blancher F, Wagniere S, Mansourian R, Zbinden I, Leone-Vautravers P, Fuerholz A, Giusti V, Macé K: Contribution of mesothelial cells in the expression of inflammatory-related factors in omental adipose tissue of obese subjects. Int J Obes (Lond) 2008;32:112-120.

-73 Henegar C, Tordjman J, Achard V, Lacasa D, Cremer I, Guerre-Millo M, Poitou C, Basdevant A, Stich V, Viguerie N, Langin D, Bedossa P, Zucker JD, Clement K: Adipose tissue transcriptomic signature highlights the pathological relevance of extracellular matrix in human obesity. Genome Biol 2008;9:R14.

74 Hayden MR: Calciphylaxis and the cardiometabolic syndrome: the emerging role of sodium thiosulfate as a novel treatment option. J Cardiometab Syndr 2008;3:55-59.

-75 Sowers KM, Hayden MR: Calcific uremic arteriolopathy: pathophysiology, reactive oxygen species and therapeutic approaches. Oxid Med Cell Longev 2010;3:109-121.

76 Bergman RN, Ader M: Free fatty acids and pathogenesis of type 2 diabetes mellitus. Trends Endocrinol Metab 2000; 11:351-356.

77 Ludwig J, Viggiano TR, McGill DB, Oh BJ: Nonalcoholic steatohepatitis: Mayo Clinic experiences with a hitherto unnamed disease. Mayo Clin Proc 1980;55:434-438.

78 Ludwig J, McGill DB, Lindor KD: Review: nonalcoholic steatohepatitis. J Gastroenterol Hepatol 1997;12:398-403.

79 Hayden MR, Stump CS, Sowers JR: Introduction: organ involvement in the cardiometabolic syndrome. J Cardiometab Syndr 2006;1:16-24.

80 Abdeen MB, Chowdhury NA, Hayden MR, Ibdah JA: Nonalcoholic steatohepatitis and the cardiometabolic syndrome. J Cardiometab Syndr 2006;1:36-40.

81 Cortez-Pinto H, de Moura MC, Day CP: Non-alcoholic steatohepatitis: from cell biology to clinical practice. J Hepatol 2006;44:197-208.

82 Wei Y, Clark SE, Morris EM, Thyfault JP, Uptergrove GM, Whaley-Connell AT, Ferrario CM, Sowers JR, Ibdah JA: Angiotensin II-induced non-alcoholic fatty liver disease is mediated by oxidative stress in transgenic TG(mRen2)27(Ren2) rats. J Hepatol 2008;49:417-428.

83 Tolman KG, Dalpiaz AS: Treatment of non-alcoholic fatty liver disease. Ther Clin Risk Manag 2007;3:1153-1163.

84 Toblli JE, Muñoz MC, Cao G, Mella J, Pereyra L, Mastai R: ACE inhibition and AT1 receptor blockade prevent fatty liver and fibrosis in obese Zucker rats. Obesity (Silver Spring) 2008;16:770-776.

85 Leung PS, Chappell MC: A local pancreatic renin-angiotensin system: endocrine and exocrine roles. Int J Biochem Cell Biol 2003;35:838-846.

-86 Leung PS, de Gasparo M: Involvement of the pancreatic renin-angiotensin system in insulin resistance and the metabolic syndrome. J Cardiometab Syndr 2006;1:197-203.

87 Hayden MR: Islet amyloid and fibrosis in the cardiometabolic syndrome and type 2 diabetes mellitus. J Cardiometab Syndr 2007;2:70-75.

88 Hayden MR, Sowers JR: Treating hypertension while protecting the vulnerable islet in the cardiometabolic syndrome. J Am Soc Hypertens 2008;2:239-266.

89 Hayden MR, Karuparthi PR, Habibi J, Lastra G, Patel K, Wasekar C, Manrique CM, Ozerdem U, Stas S, Sowers JR: Ultrastructure of islet microcirculation, pericytes and the islet exocrine interface in the HIP rat model of diabetes. Exp Biol Med (Maywood) 2008;233:1109-1123. 


\section{CardioRenal Medicine}

Cardiorenal Med 2011;1:193-210

\begin{tabular}{l|l}
\hline DOI: $10.1159 / 000329926$ & (c) 2011 S. Karger AG, Basel
\end{tabular}

Published online: July 30, 2011

Hayden et al.: Mechanisms of Local tRAS Activation

90 Butler AE, Jang J, Gurlo T, Carty MD, Soeller WC, Butler PC: Diabetes due to a progressive defect in beta-cell mass in rats transgenic for human islet amyloid polypeptide (HIP rat): a new model for type 2 diabetes. Diabetes 2004;53: 1509-1516.

91 Matveyenko AV, Butler PC: $\beta$-Cell deficit due to increased apoptosis in the human islet amyloid polypeptide transgenic (HIP) rat recapitulates the metabolic defects present in type 2 diabetes. Diabetes 2006;55:2106-2114.

-92 Matveyenko AV, Butler PC: Islet amyloid polypeptide (IAPP) transgenic rodents as models for type 2 diabetes. ILAR J 2006;47:225-233.

93 Zhao HL, Sui Y, Guan J, He L, Gu XM, Wong HK, Baum L, Lai FM, Tong PC, Chan JC: Amyloid oligomers in diabetic and nondiabetic human pancreas. Transl Res 2009;153:24-32.

94 Zhao HL, Lai FM, Tong PC, Zhong DR, Yang D, Tomlinson B, Chan JC: Prevalence and clinicopathological characteristics of islet amyloid in Chinese patients with type 2 diabetes. Diabetes 2003;52:2759-2276.

-95 Tikellis C, Wookey PJ, Candido R, Andrikopoulos S, Thomas MC, Cooper ME: Improved islet morphology after blockade of the renin-angiotensin system in the ZDF rat. Diabetes 2004;53:989-997.

-96 von Lutterotti N, Catanzaro DF, Sealey JE, Laragh JH: Renin is not synthesized by cardiac and extrarenal vascular tissues. A review of experimental evidence. Circulation 1994;89:458-470.

-97 Rossi GP, Sacchetto A, Cesari M, Pessina AC: Interactions between endothelin-1 and the renin-angiotensin-aldosterone system. Cardiovasc Res 1999;43:300-307.

-98 Seccia TM, Belloni, Kreutz R, Paul M, Nussdorfer GG, Pessina AC, Rossi GP: Cardiac fibrosis occurs early and involves endothelin and AT-1 receptors in hypertension due to endogenous angiotensin II. J Am Coll Cardiol 2003;41:666-673.

99 Mulder P, Richard V, Derumeaux G, Hogie M, Henry JP, Lallemand F, Compagnon P, Macé B, Comoy E, Letac B, Thuillez C: Role of endogenous endothelin in chronic heart failure: effect of long-term treatment with an endothelin antagonist on survival, hemodynamics, and cardiac remodeling. Circulation 1997;96:1976-1982.

100 Pitt B, Zannad F, Remme WJ, Cody R, Castaigne A, Perez A, Palensky J, Wittes J: The effect of spironolactone on morbidity and mortality in patients with severe heart failure. Randomized Aldactone Evaluation Study Investigators. N Engl J Med 1999;341:709-717.

101 Pitt B, Williams G, Remme W, Martinez F, Lopez-Sendon J, Zannad F, Neaton J, Roniker B, Hurley S, Burns D, Bittman R, Kleiman J: The EPHESUS Trial: eplerenone in patients with heart failure due to systolic dysfunction complicating acute myocardial infarction. Eplerenone Post-AMI Heart Failure Efficacy and Survival Study. Cardiovasc Drugs Ther 2001;15:79-87.

102 Dostal DE: The cardiac renin-angiotensin system: novel signaling mechanisms related to cardiac growth and function. Regul Pept 2000;91:1-11.

103 Liu J, Divoux A, Sun J, Zhang J, Clement K, Glickman JN, Sukhova GK, Wolters PJ, Du J, Gorgun CZ, Doria A, Libby P, Blumberg RS, Kahn BB, Hotamisligil GS, Shi GP: Genetic deficiency and pharmacological stabilization of mast cells reduce diet-induced obesity and diabetes in mice. Nat Med 2009;15:940-945.

104 Silver RB, Reid AC, Mackins CJ, Askwith T, Schaefer U, Herzlinger D, Levi R: Mast cells: a unique source of renin. Proc Natl Acad Sci USA 2004;101:13607-13612.

105 Metcalfe DD, Baram D, Mekori YA: Mast cells. Physiol Rev 1997;77:1033-1079.

106 Holdsworth SR, Summers SA: Role of mast cells in progressive renal diseases. J Am Soc Nephrol 2008;9:2254-2261.

107 Whaley-Connell A, Pulakat L, DeMarco VG, Hayden MR, Habibi J, Henriksen EJ, Sowers JR: Overnutrition and the cardiorenal syndrome: use of a rodent model to examine mechanisms. Cardiorenal Med 2011;1:23-30.

108 Hayden MR, Tyagi SC: Islet redox stress: the manifold toxicities of insulin resistance, metabolic syndrome and amylin derived islet amyloid in type 2 diabetes mellitus. JOP 2002;3:86-108.

109 Hayden MR, Tyagi SC: Myocardial redox stress and remodeling in metabolic syndrome, type 2 diabetes mellitus, and congestive heart failure. Med Sci Monit 2003;9:SR35-SR52.

-110 Prasad A, Quyyumi AA: Renin-angiotensin system and angiotensin receptor blockers in the metabolic syndrome. Circulation 2004;110:1507-1512.

111 Hayden MR, Whaley-Connell A, Sowers JR: Renal redox stress and remodeling in metabolic syndrome, type 2 diabetes mellitus, and diabetic nephropathy: paying homage to the podocyte. Am J Nephrol 2005;25:553-569.

112 Hayden MR, Chowdhury NA, Cooper SA, Whaley-Connell A, Habibi J, Witte L, Wiedmeyer C, Manrique CM, Lastra G, Ferrario C, Stump C, Sowers JR: Proximal tubule microvilli remodeling and albuminuria in the Ren2 transgenic rat. Am J Physiol Renal Physiol 2007;292:F861-F867.

113 Hayden MR, Tyagi SC: Neural redox stress and remodeling in metabolic syndrome, type 2 diabetes mellitus, and diabetic neuropathy. Med Sci Monit 2004;10:RA291-RA307.

114 De Nuccio I, Salvati G, Genovesi G, Paolini P, Marcellini L, Schiavello V, Re M: Physiopathology of the renin-angiotensin system in the ovary. Minerva Endocrinol 1999;24:77-81.

115 Brunswig-Spickenheier B, Mukhopadhyay AK: Local regulatory factors in regulation of ovarian function: role of prorenin-renin-angiotensin-system. Indian J Exp Biol 2003;41:669-681.

116 Strain WD, Chaturvedi N: The renin-angiotensin-aldosterone system and the eye in diabetes. J Renin Angiotensin Aldosterone Syst 2002;3:243-246.

117 Gilbert RE, Krum H, Wilkinson-Berka J, Kelly DJ: The renin-angiotensin system and the long-term complications of diabetes: pathophysiological and therapeutic considerations. Diabet Med 2003;20:607-621. 